JOVAN P. ŠETRAJČIĆ*

University of Novi Sad, Faculty of Sciences, Department of Physics, Novi Sad, Vojvodina, Serbia

Review paper

ISSN 0351-9465, E-ISSN 2466-2585

UDC:620.18(n)

doi:10.5937/ZasMat1601081S

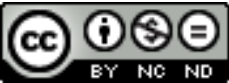

Zastita Materijala 57 (1)

81 - $92(2016)$

\title{
Research of properties of nanoscopic structures
}

\begin{abstract}
Aim of this paper is creation of model of ultrathin films, superlattices, nano wires and quantum dots, and investigations microscopic and macroscopic properties of these low-dimensional crystal systems. It was demonstrated that reducing space dimensions and boundary conditions has great influence on the physically relevant properties in these crystal substances. Resonant absorption, different behavior of specific heat and critical superconductive temperatures up to $100{ }^{\circ} \mathrm{C}$ were explained.
\end{abstract}

Keywords: ELectrons, phonons, excitons, molecular structures, high-temperature superconductivity, ultrathin films, superlattices, nano wires, quantum dots.

\section{INTRODUCTION}

Even today, two decades since the invention of high-temperature superconductive ceramics [1-5], the mechanism of superconductivity has not been discovered. Undertaking the research on the possible improvement of superconductive characteristics and quite some time before this discovery [6-14], we paid our attention to the examination of conditions that 'raise' the quality of critical hightemperature superconductors' parameters.

Low-dimensional structures (ferromagnetics, ferroelectrics, dielectrics and conductors) were modeled and examined in a research group led by Academician, Prof. Dr. Bratislav S. Tošić already in the seventies. Semi definite crystalline systems were dealt with first [6-8], and later films [9-23], because of their interesting appearance: separation of localized surface states [9-24].

\section{PROBLEMS OF NANO}

The discovery of high-temperature superconductors: their 'exotic' structure - doped perovskites and the anisotropy of physical characteristics, together with our own founding on the impact of the

\footnotetext{
*Corresponding author: Jovan Šetrajčić

E-mail: jovan.setrajcic@df.uns.ac.rs

Paper received: 11. 11. 2015.

Paper accepted: 31. 12. 2015.

Paper is available on the website: www.idk.org.rs/casopis
}

system limits to microscopic features of materials gave us some new hope and the willingness to thoroughly work on the consequences of extreme division into layers (e.g. 2D - those are surfaces $\alpha$, $\beta$ and $\gamma$ or 1D - lines $a, b, c, d$ and $e$, shown on Figure 1), lack of isotropy, translational invariance, ...

Being convinced that we can help in solving the riddle about the potential or possible mechanism, i.e. mechanisms of superconductivity of hightemperature copper-oxide ceramics; we actualized our research and focused them to:

- Preparation of model - thin films and

- Use of 'newer' mathematics - quasi-discrete analyses, because we spotted alternating crystal layers (brimmed or limited by 2D surfaces).

These lawyers - thin films (because they contain only a few complex crystallographic surfaces parallel with boundaries) and the attitude of elementary awakenings in them dictate the characteristics of the whole sample.

Even during the period between 1987 - 1993 and until now, we had a series of very significant results that retain proven BCS approach to Cooper's couples of electrons or holes, tightly bound by phonons of optical type, but in crystal systems that are

- Spaciously extremely limited and

- Translationally non-invariant. 


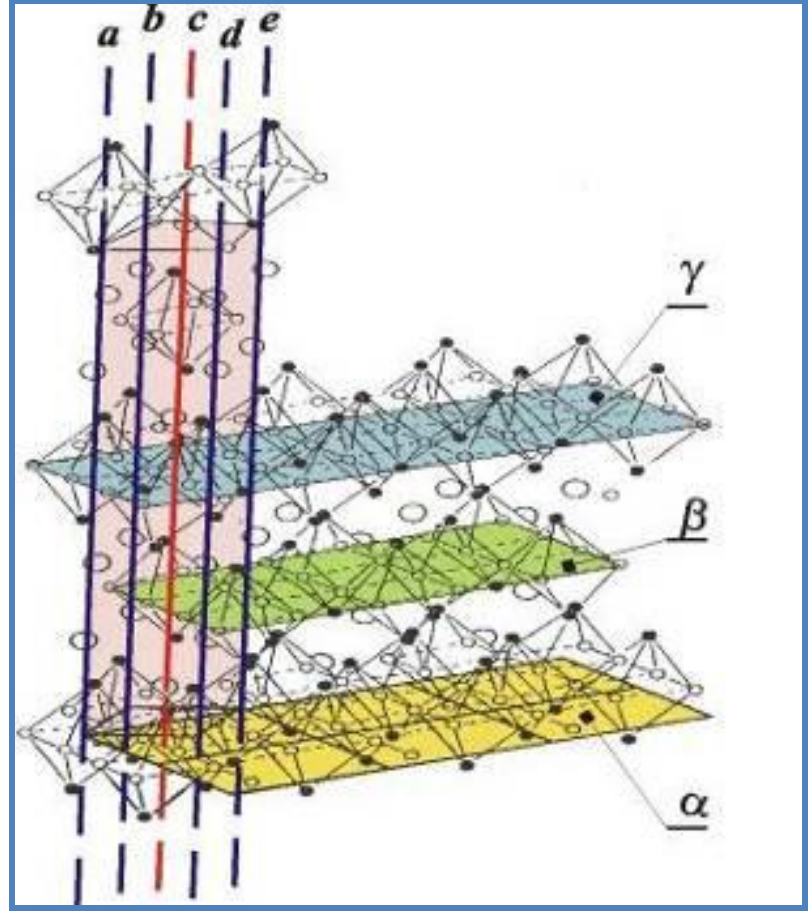

Figure $1-2 D$ surfaces and $1 D$ chains $Y-B a-C u-O$ ceramics

\section{DIMENSIONAL QUANTIZATION}

This notion is the result of contemporary research and refers to the appearance of quantum effects at macroscopic level as a consequence of drastic decrease of dimensions of analyzed samples.

Theoretical treatment of these problems is adequate only by using a specific mathematical calculus: discrete analyses, which introduce differences and anti-differences $\left(\Delta\right.$ and $\left.\Delta^{-1}\right)$, instead of differentials and integrals $(d$, i.e. $\delta$ and $\varsigma$ ). Experimental and theoretical results directly imply the absence of classical principle of causality and opposite from that - they stress enormous change of physical characteristics!

In order to comply with such a strict demand, we adapted the method of Green's functions. Their determination ${ }^{1}$ became the result of a system of a finite number of differential equations, with the correlation between a certain boundary conditions. The existence of the solution of this problem defines energy spectra and possible states of elementary awakenings, and they define thermodynamics and the other macroscopic behaviors.

${ }^{1}$ Finding a solution - original operator solution is a result of serious work of a group of researchers around Academician Tošić. This opens the possibilities to find specificities in microscopic features of samples!

\section{NANO-CRYSTALLINE STRUCTURES}

\subsection{Ultrathin films}

Noticing extreme two-dimensionality of a crystalline structure (e.g. surfaces $\alpha, \beta$ and $\gamma$ shown at Figure 1), at first we made a model of ultra-thin films with a primitive cell (mono-atomic, i.e. monomolecular or mono-ion film ${ }^{2}$, Figure $2 a-$ for a phonon film), and later we defined a model with sub lattices (bi-atomic/molecular/ionic film, Figure $2 b$ - for an electron film). A basic feature of ultrathin film models is that they have two parallel boundary areas with up to ten parallel crystallographic surfaces between them. Physical characteristics of the above-mentioned boundary areas need not be the same, because they can touch two different substances (substrate and outer environment). Besides that, physical characteristics of boundary line connections (those between boundary areas and their neighboring crystallographic surfaces) can greatly differ from inner film layers.

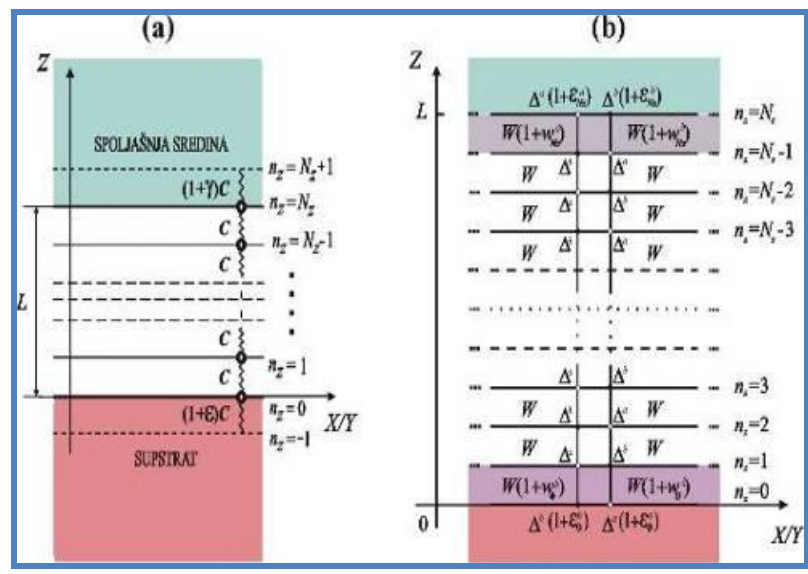

Figure 2 - Models of ultra-thin crystalline films

\subsection{Superlattices}

A specific model of crystalline structures representing a string of 'glued' ultrathin films is called a super lattice. Their basic feature is that they have macroscopic cell - a motive that repeats an infinite number of times. The motive is consisted of different ultrathin crystalline films. It is important to find out physical characteristics of the motives and their behavior.

The Figure 1 shows a crystalline film 'placed' between boundary surfaces $\alpha$ and $\beta$, and another one between $\beta$ and $\gamma$. If we can reproduce or model the whole structure of the crystalline sample shown

2 Depending on the motive: atom, molecule or e.g. ion, found in the junctions of crystalline lattices of that film. Further in the text we will only use the adjective: atomic, bearing on mind all the above-mentioned motives. 
above by permanent 'stitching/gluing' of such paired films $(\alpha-\beta+\beta-\gamma)$ to those already existing, then this pair of films makes a basic motive of

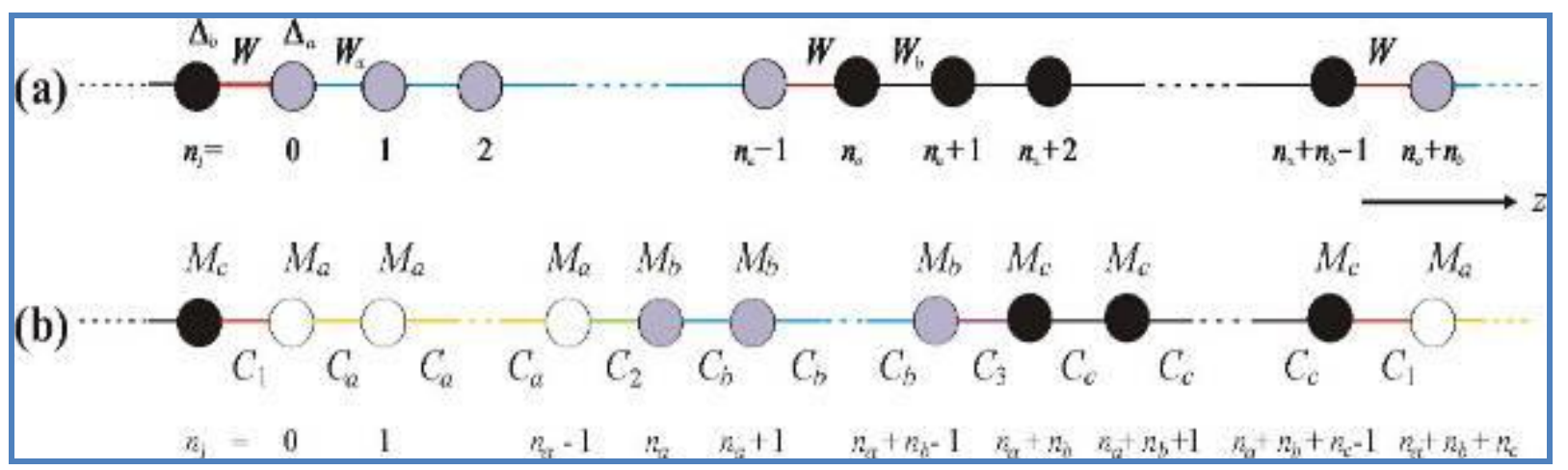

Figure 3 - Models of crystalline super lattices

We have formed and analyzed two kinds of super lattices: with two $\left(A_{n} B_{m}\right.$, Figure $\left.3 a\right)$ and three films $\left(A_{n} B_{m} C_{l}\right.$, Figure $\left.3 b\right)$. In them $n$, and $m$, i.e. $n$, $m$ and $I$ are single digit whole numbers - numbers of atoms/ions/molecules of $A$ and $B$, i.e. of $A, B$ and $C$ kind, respectively - those that build crystalline lattice of those films. Each film has its own boundary characteristics, i.e. there are specific boundary line conditions at film and motive rims.

\subsection{Quantum wires}

Models of crystalline structures that are limited along two directions and of small dimensions along those two directions are in the literature called quantum wires or nanorods. Such structures are shown on the Figure 1: its brims are marked with $a$, super lattice, and the whole sample - exactly that super lattice.

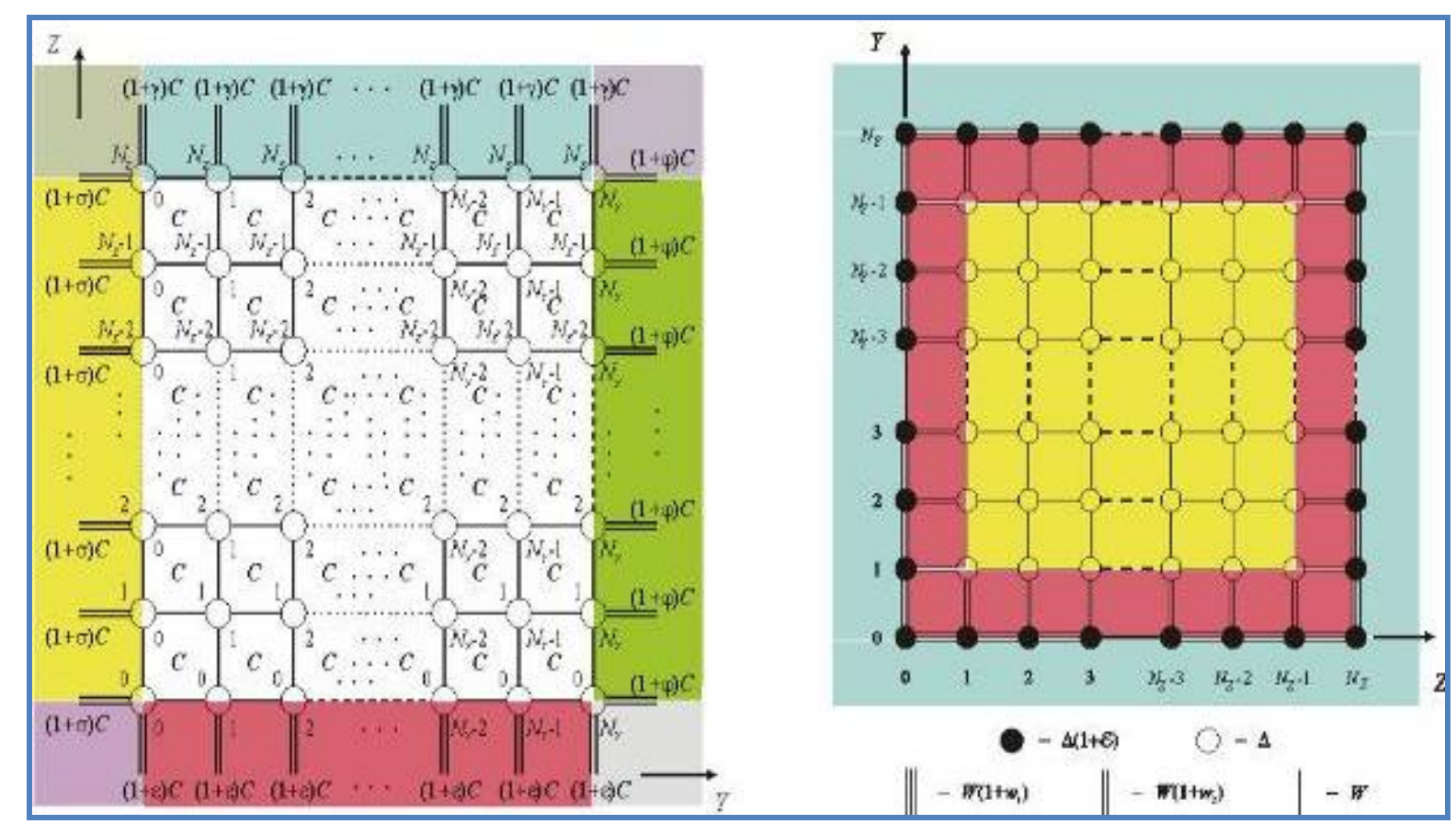

a)

$b, d$ and $e$. Its anisotropy is further complicated by the existence of the chains of atoms located within this quantum wire - along the marked direction $c$.

They are quasi-one-dimensional and, in general case, they have four boundary line areas (those are surfaces $a-b, b-d, d-e$ and $e-a$,) with changed parameters on those areas and in boundary layers. They are also called quantum beams. The Figure 4 shows the models of phonon (a) and electron (b) quantum wires.

A special shape of quantum wires possesses cylindrical quantum wires or nanotubes, which appear in two different shapes: as full or empty cylinders.

b)

Figure 4 - Models of crystalline quantum wires 


\subsection{Quantum dots}

Models of crystalline structures that are limited along all three directions and of rather small (nano)dimensions are in literature called quantum dots (Figure 5). They can be of rather different shape, but in research they are usually rectangular (nano-quadrangles) and disc-shaped (full and/or empty discs).
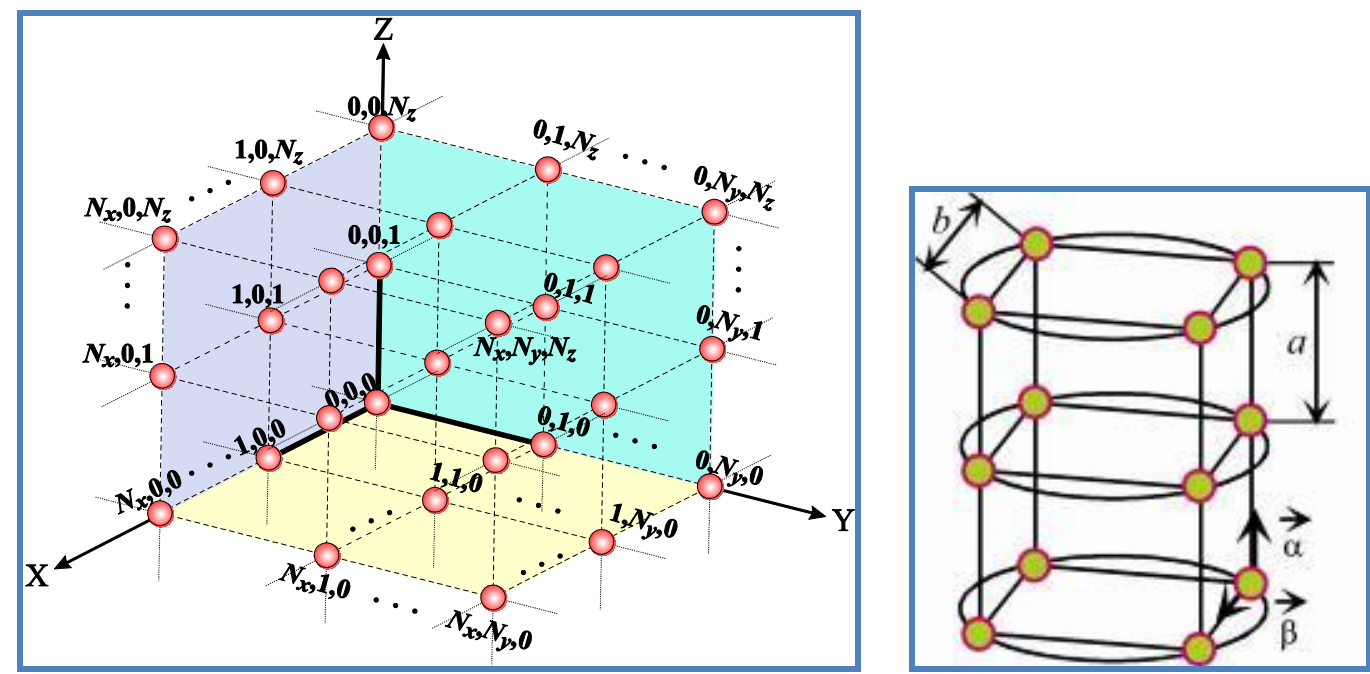

Figure 5 - Quadratic and cylindrical crystalline quantum dot models

\section{MICRO (NANO)-SCOPIC FEATURES}

Fundamental characteristics of elementary quasi-particles that appear and can be treated as special subsystems within the framework of the examined model - microscopic feature are: spectrum of energetic states (dispersion law) and the distribution of these states. Due to the fact that these characteristics define the behavior of macroscopic features, the most important thing was to notice essential differences of these characteristics in comparison to the same ones in their corresponding unlimited structures.

\subsection{Spectra of elementary excitations}

The areas of allowed and forbidden energies of elementary excitations (of phonons and electrons) were defined first, as well as their major micro theoretical characteristics (Figure 6).

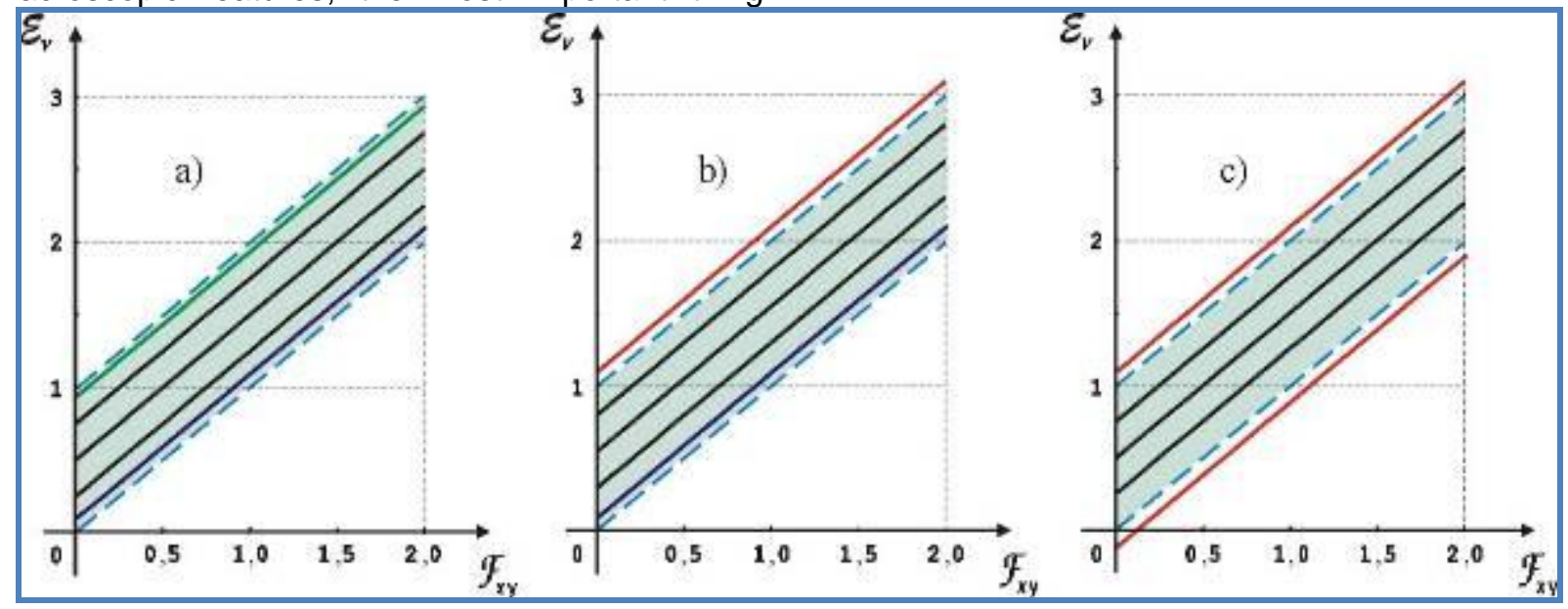

Figure 6 - Dispersion low of elementary excitations of ultrathin film

In contrast to the continuous zone of allowed energies of monitored excitations in bulkstructures, in extremely limited (nano) structures the allowed energy zone becomes 'shredded' into a precisely defined number of discrete sub zones. The width of the zone and the position of allowed (extremely discrete) energies of very limited (nano) structures can drastically differ from bulk-structures with the same crystalline order. Some possible cases were illustrated on Figure 6 for a model of ultra thin film: narrowing of allowed-energy zone (a), moving of that zone and the appearance of a strong localized state (b) as well as the broadening of the zone outside bulk boundaries and the appearance of two localized states (c). 
A direct consequence of the change of the allowed-energy zone width is a possible appearance of localized - separated energy states and/or the appearance of additional energy gaps ${ }^{3}$. Electron gaps occurrence and dependence of the number of layers in ultrathin films are presented in Fig. 7.

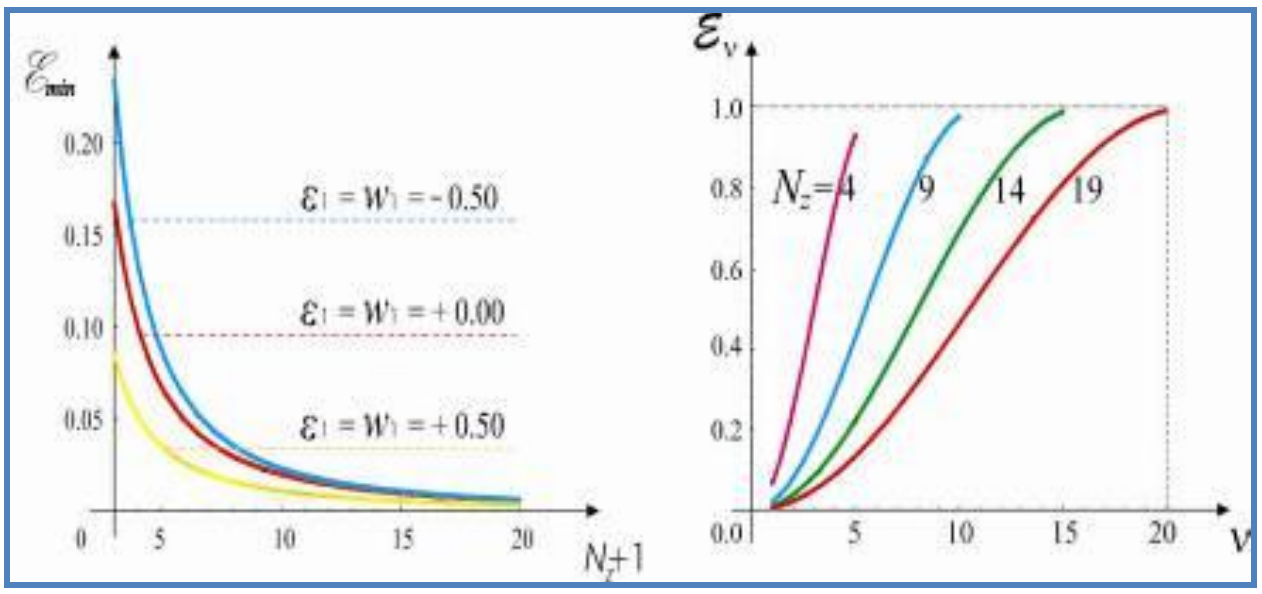

Figure 7 - Gaps occurrence and dependence of the number of layers in films

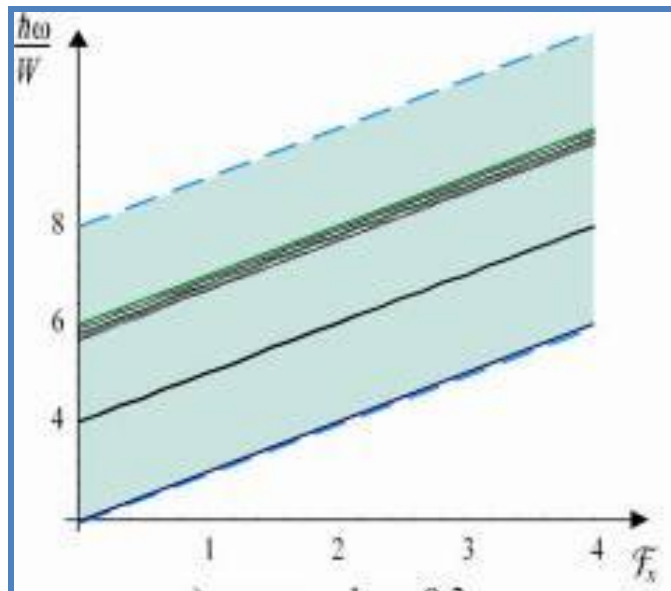

a) $\omega=\omega_{2}=-1 ; \varepsilon=0.3$

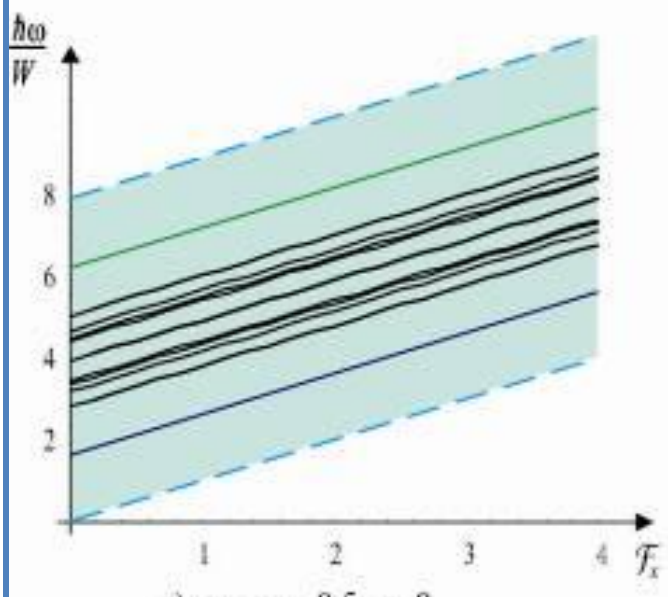

c) $\omega_{1}=\omega_{2}=-0.5 ; \varepsilon=0$

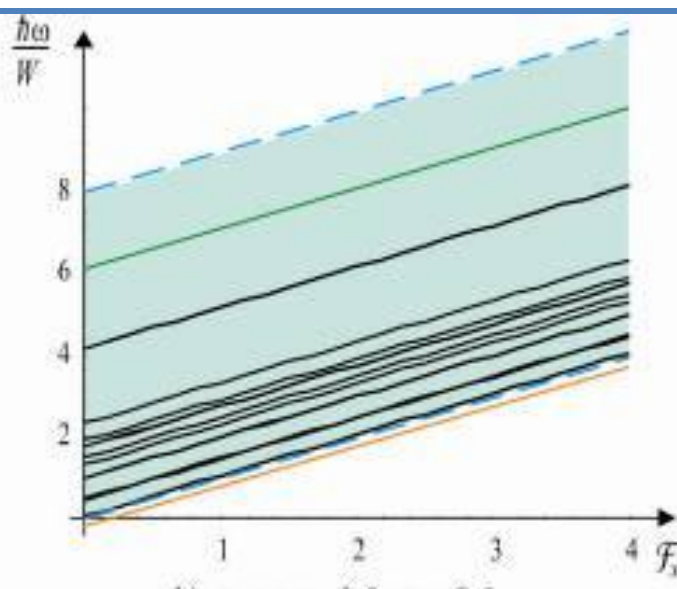

b) $\omega_{1}=\omega_{2}=-0.5 ; \varepsilon=-0.5$

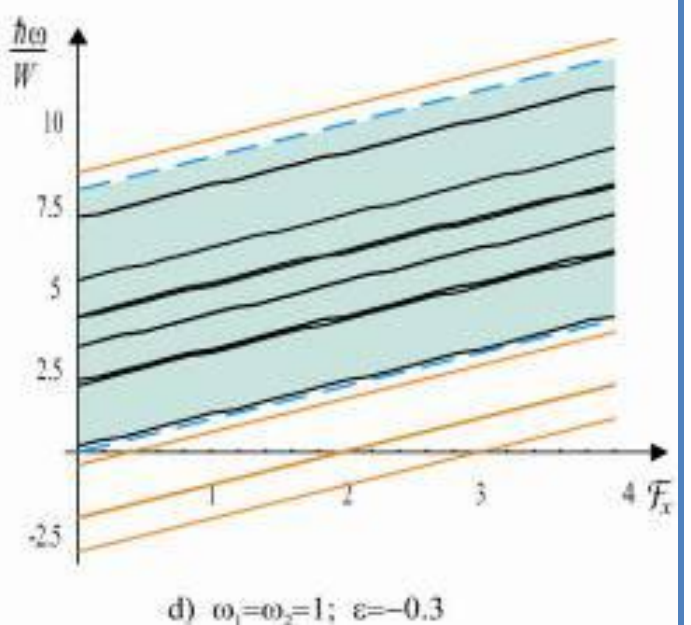

d) $\omega_{1}=0,0=1 ; \varepsilon=-0.3$

Figure 8 - Dispersion low of elementary charge excitations of nanowire

$\overline{3}$ Due to changed width o allowed-energy zone a definition of the size of Brillouin's area and/or the position of Fermi's level. 
The appearance of lower energy gaps is described by necessary activating heat - energy, which has to be introduced in order to have monitored elementary awakenings in subsystem. Energy gaps occurrence are clearly seen from dispersion low of elementary charge excitations of nanowire (Fig. 8).

\subsection{States of elementary excitations}

Beside the possibility to change and the presence of energy spectra as well as possible appearance of localized states a crucial question is how big is the possibility or statistical presence of the appearance of the states found and, especially and possibly the most important, what about their spatial division. The space distribution (probability of occurrence of electronic states through filmwidth) of the elementary charge excitations states in center and in end of Brillouin's zone of the ultrathin film in the function of layers position are graphically presented in Fig. 9.

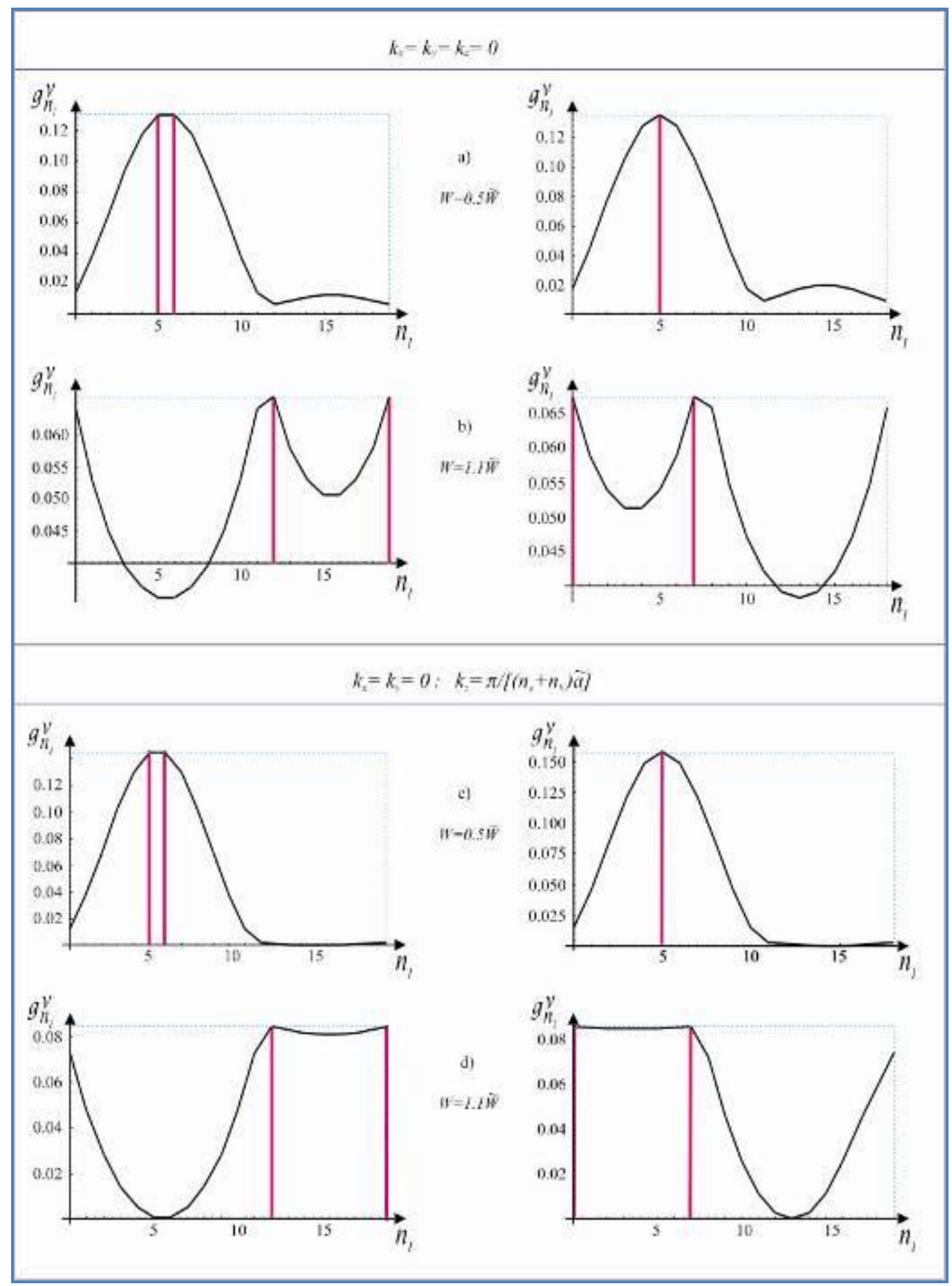

Figure 9 - Distribution of the elementary excitations states in center and in end of Brillouin's zone of the film 


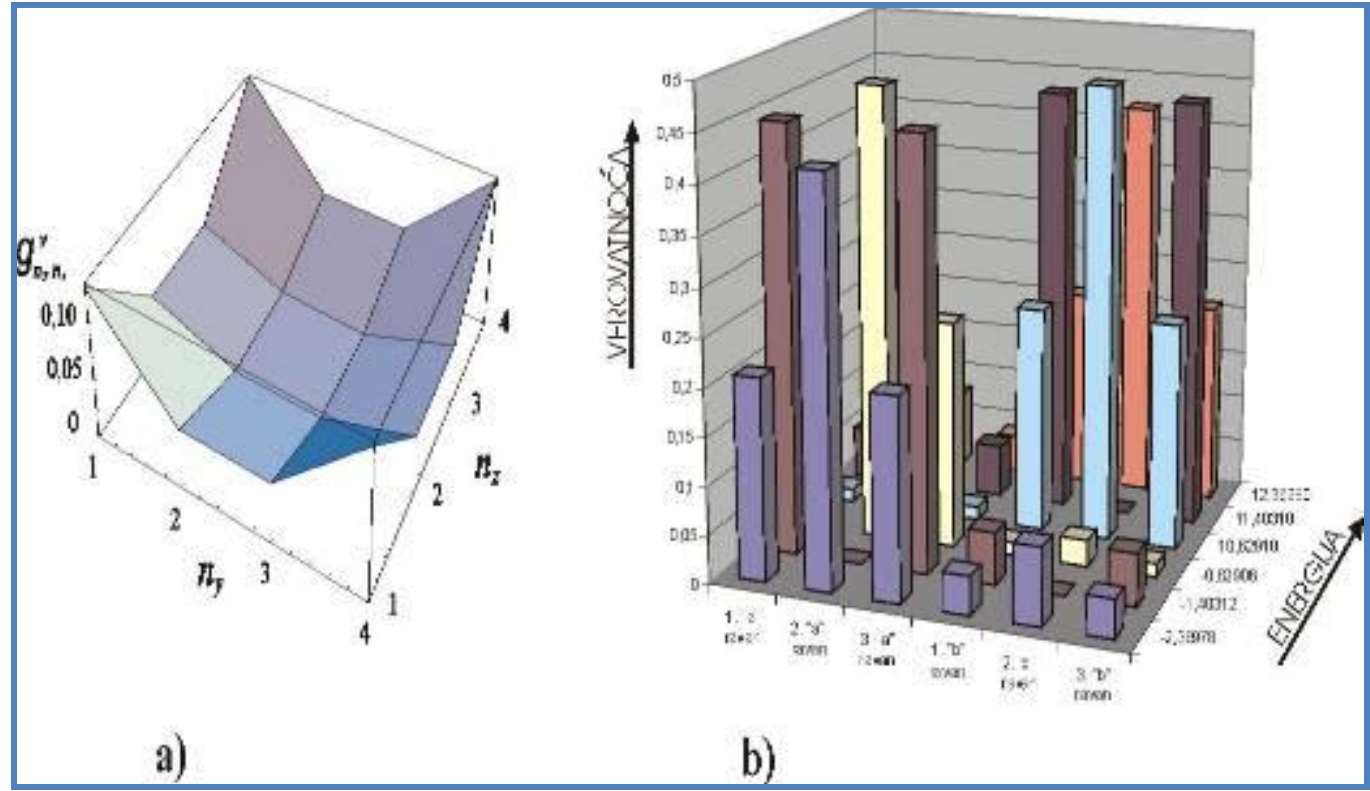

Figure 10 - Distribution of the states of elementary excitations

The following Figures show densities and spatial divisions of energy states of bi-film motive of electronic super lattice. Figures $10 \mathrm{a}$ and $10 \mathrm{~b}$ showed spatial divisions of energy levels of phonon quantum wire and electronic film, respectively, with visible skin effects.

\section{THERMODYNAMIC FUNCTIONS AND TRANSPORT CHARACTERISTICS}

The knowledge about the behavior of thermodynamic functions and the distribution of transport values enables the determination of macroscopic characteristics of monitored nano- crystalline structures. Phonon and electronic shares in heat capacity of film-structures and super-lattices are well described, followed by the phonon share in heat conductivity of film-structures and super-lattices, while the research on transport features are still in progress.

Figure 11 shows temperature behavior of electronic share in heat capacity (a) and phonon share in heat conductivity (b) of film-structures and super-lattices. The results were compared with the appropriate bulk ones. It is visible that the effects made by film-boundaries are 'ironed', i.e. spoiled by super-lattice.
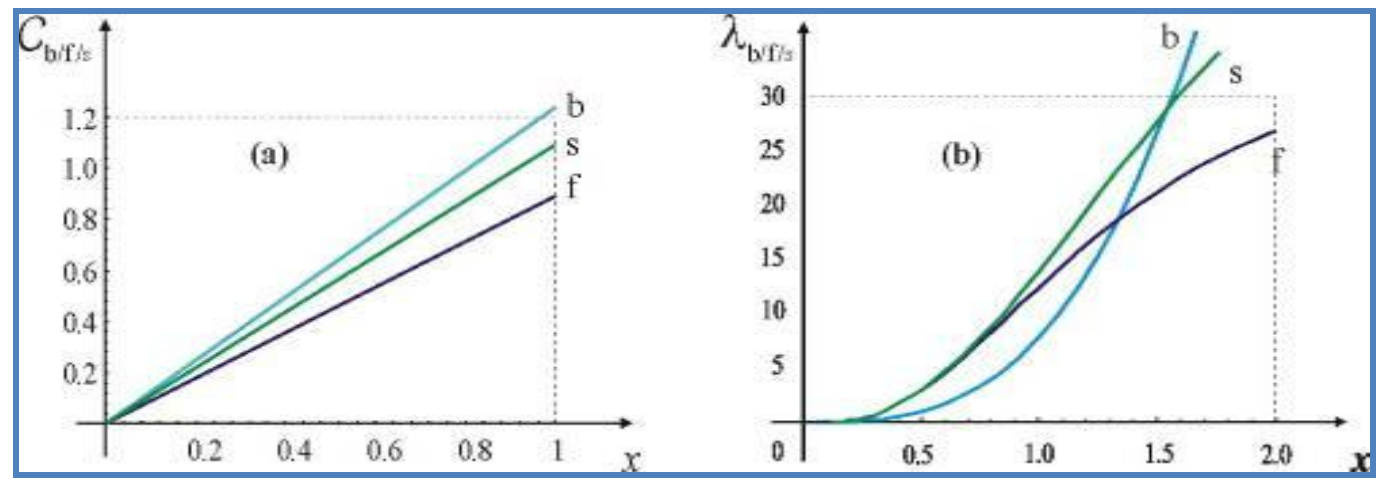

Figure 11 - Heat characteristics of ultra thin films and super-lattices

\section{RESEARCH REASONS, ACHIEVED RESULTS AND PERSPECTIVES}

The precise structuring of materials to the dimensions of the order of nanometer is of great importance in electronics, optoelectronics, high temperature superconductivity, biology, medicine, environmental protection and many other scientific and technological disciplines. Theoretical and experimental studies of properties of low- dimensional systems (ultrathin films, superlattices, quantum wires and points), have become very intense in recent decades, so it could be concluded that they represent one of the key directions of research in modern condensed matter physics.

The development of sophisticated techniques for the growth control of very thin layers caused intensive research of the nano-crystalline structures. One of the basic principles for their 
production is based on a process of selfconstruction or self-assembly $[56,57]$ which is one of the "bottom-up" techniques, in which atoms or molecules arrange themselves into low-dimensional structures on the basis of mutual physical-chemical interactions. Although the self-assembly has been known for many years, its use in industry is still at the beginning. Improved knowledge of thermodynamics and kinetics of the nano-scale processes, with the advancement of characterization techniques and computer modelling, should lead to the development of complex systems.

Application of nanostructures requires knowledge of their fundamental physical (mechanical, electromagnetic, optical, etc.) characteristics [5860]. Theoretical investigations of low-dimensional crystalline systems (nanostructures: ultrathin films, quantum wires, points etc.) have been intensified recently in order to obtain fundamental information relating to extremely different physical and chemica properties of material, and also due to their wide practical application (technical and technological) in nano-, opto- and bio-electronics [61-63]. Specificity of these "tiny" structures is that presence of near boundary planes causes highly changed general properties of these materials and occurrence of nonspecific phenomena (as a consequence of quantum size - QSE and confinement effects [6264]) in comparison to the properties of corres ponding "large" samples.

Nevertheless, the uncharted part of lowdimensional samples properties is the one due to presence of physically different structure boundaries and changed fundamental energy parameters of elementary excitation systems at those boundaries, i.e. in the boundary layers. Changing values of these parameters that correspond to levels of intermolecular interactions in boundary regions has the important role in creating differences in physical properties of nanoscopic structures in comparison to corresponding bulk structures [65-67]. This was investigated in molecular crystalline nano-films, which are typical examples of optically active materials. Their properties are described using quasi-particle model of Frenkel's excitons and most essential results will be presented here.

Research of the influence of quantum size and confinement effects in nanostructures is not new. Reduction of sizes in nanostructures leads to the so-called confinement of elementary excitation due to which their branches are quantized (dimensional quantization) and a substantive modification of their energy spectrum, group velocity and polarization occur. Due to the reflections from the inner surface of the structure, elementary excitations hybridize or localize and cease to be transparent, and their energy is reduced compared to the case in the bulk structure.

The absorption of photons in dielectric solid can lead to located excitations - Frenkel's excitons which are responsible for organic crystals optical characteristics $[68,69]$. Interest in the study of exciton subsystem appeared because excitons are responsible for dielectric, optic (absorption, dispersion and luminescence), photoelectric and other properties of crystals [68-70]. Ultrathin organic (dielectric) films are of potential importance for future electronic compounds and optic devices and they are in the focus of current intensive studies [70].

Theoretical studies of quasi-two-dimensional exciton systems became rather intense, especially in application of device packaging. Electronic components are used today in extreme physical conditions and in that sense, ultrathin dielectric crystalline films could be used as surface layers for electronic component protection $[71,72]$.

During the past decade, we have studied the basic physical characteristics of different ultrathin crystalline films [73--85], and one can see that essential properties of these systems arise with perturbation conditions which appear at and within their surface layers. Based on the formed models of ultrathin films, super-lattices, quantum wires and dots, as well as monitored microscopic and macroscopic features of such crystalline systems, we showed an extremely large influence of the decrease of spatial dimensions and boundary conditions to the change of physically relevant (optics, thermodynamics and electro transporting) characteristics of crystal substances [86-100]. Critical temperatures up to $100 \mathrm{~K}$ are explained here: although the effects of electron-phonon interaction (as in BSC-theory) are still not calculated. We presented here the results of theoretic research conducted within last twenty years ${ }^{4}$.

\footnotetext{
${ }^{4}$ In the period since 1994 from this thematic:

16 doctoral dissertations and master's thesis were defended - 10 people are abroad,

- 17 monographs were prepared and printed - 9 of international significance,
}

Over 200 scientific works were published - 120 in international journals and proceedings

Results were presented at scientific conferences 150 times - half of the number were international events.

The methodology of research was developed and results are obtained: for films and super-lattices, partially for quantum dots, but not for quantum super-lattices and super-active super-lattices

A major objection to this research is that they were focused on hypothetic crystalline structures and their models. Their connection with some experimental and technical-technology group would probably resolve this problem. 


\section{Acknowledgements}

The greatest thanks the author owes to his teacher, mentor and friend, unfortunately, recently deceased Academician, Prof. Dr. Bratislav S. Tošić. His proper and quality oriented suggestions had crucial impact on the value and importance of this work.

This paper was in part supported by the Serbian Ministry of Education, Science and Technological Development (Grants: ON-171039 and TR-34019) and Ministry of Science and Technology (Grants: 19/6-020/961-23/14) as well as the Vojvodina Provincial Secretariat for Science and Technological Development (Grant 114-451972).

\section{REFERENCES}

[1] D.Esteve, J.M.Martinis, C.Urbina, M.H.Devoret, G.Collin, P.Monod, M.Ribault, A.Revcolevschi (1987) Observation of the a.c. Josephson effect inside copper-oxide-based superconductors, Europhysics Lett., 3, 1237-1245.

[2] P.H.Hor, R.L.Meng, Y.Q.Wang, L.Gao, Z.J.Huang, J.Bechtold, K.Forster, C.W.Chu (1987) Superconductivity above $90 \mathrm{~K}$ in the square-planar compound system $\mathrm{ABa} 2 \mathrm{Cu} 3 \mathrm{O} 6+\mathrm{x}$ with $\mathrm{A}=\mathrm{Y}, \mathrm{La}, \mathrm{Nd}$, $\mathrm{Sm}, \mathrm{Eu}, \mathrm{Gd}, \mathrm{Ho}, \mathrm{Er}$ and Lu, Phys.Rev.Lett., 58, 1891-1902.

[3] P.W.Anderson (1987) The resonating valence bond state in La2CuO4 and superconductivity; Science, 235, 1196-1204.

[4] J.G.Bednorz, K.H.Muller (1988) Perovskite-type oxides - The new approach to high-Tc superconductivity. Rev.Mod.Phys, 60, 585-592.

[5] V.V.Schmidt (1997) The Physics of Superconductors, Springer, Berlin.

[6] Lj.D.Mašković, D.V.Kapor, J.P.Šetrajčić, B.S.Tošić (1986) Kinematical and dynamical interaction do not change properties of two-particle solitons, Phys.Lett., 114A, 289-291.

[7] S.D.Stojanović, J.P.Šetrajčić, M.J.Škrinjar, B.S.Tošić (1976) Creating of exciton drops in the exciton-phonon field, FZKAAA, 8, 111-119.

[8] S.D.Stojanović, M.J.Škrinjar, J.P.Šetrajčić (1978) On a possible realization of the superconducting state in a thin metallic film, Zbornik radova PMF-fiz.(N.Sad), 8, 153-162.

[9] M.J.Škrinjar, D.V.Kapor, J.P.Šetrajčić (1981) Low temperature properties of an anisotropic heisenberg ferromagnet, Phys.Stat.Sol.(b), 103, 559-565.

[10] D.V.Kapor, K.R.Surla, D.I.Surla, J.P.Šetrajčić, M.J.Škrinjar (1983) Anisotropy effects in an anisotropic heisenberg model, Phys.Stat.Sol.(b), 117, 9-18.

[11] M.J.Škrinjar, D.V.Kapor, J.P.Šetrajčić (1984) The validity of the low-temperature expansions for the anisotropic heisenberg models, Phys.Stat.Sol.(b), 122, 125-133.
[12] B.S.Tošić, J.P.Šetrajčić (1984) Exciton drops in onedimensional molecular chains, Phys.Stat.Sol.(b), 125, 734-183.

[13] D.Lj.Mirjanić, Z.Bundalo, B.S.Tošić, J.P.Šetrajčić (1985) Magnon drops in one-dimensional ferromagnetic structures, Phys.Stat.Sol.(b), 128, 151-158.

[14] U.F.Kozmidis-Luburić, D.Lj.Mirjanić, J.P.Šetrajčić, B.S.Tošić (1985) The influence of phonons on twoparticle states in molecular chains, Phys.Stat.Sol.(b), 128, K53.

[15] B.S.Tošić, J.P.Šetrajčić, R.P.Dajić, D.Lj.Mirjanić (1987) Phonons in broken-symmetry structures, Phys.Rev.B, 36, 9094-9101.

[16] J.P.Šetrajčić, B.S.Tošić, D.Lj.Mirjanić (1987) Superconductivity of one-dimensional metallic structures, Physica, 144A, 353-361.

[17] B.S.Tošić, J.P.Šetrajčić, U.D.Timitić, R.P.Dajić, D.Lj.Mirjanić (1988) Sputtering of ceramic matrix and phonon spectra, Int.J.Mod.Phys. B, 1, 919-926.

[18] B.S.Tošić, J.P.Šetrajčić, D.Lj.Mirjanić, R.P.Dajić (1988) Temperature effects in semi-infinite ferroelectrics, Ferroelectrics Lett., 8, 121-130.

[19] D.Lj.Mirjanić, R.P.-Dajić, B.S.Tošić, U.D.Timitić, J.P.Šetrajčić (1989) Phonon gap in anisotropic film and effects of internal energy and specific heat, FZKAAA, 21, 303-311.

[20] J.P.Šetrajčić, R.P.Dajić, D.Lj.Mirjanić, B.S.Tošić (1990) Phonon spectra in superconducting ceramics, Physica Scripta, 42, 732-743.

[21] R.P.-Dajić, B.S.Tošić, J.P.Šetrajčić, D.Lj.Mirjanić (1991) High Tc as a consequence of structure deformation, Physica C, 185, 713-724.

[22] D.Lj.Mirjanić, V.D.Sajfert, J.P.Šetrajčić, B.S.Tošić (1992) Thermodynamical characteristics of thin ferroelectric films, Ferroelectrics Lett., 14, 15-24.

[23] B.S.Tošić, J.P.Šetrajčić, D.Lj.Mirjanić, Z.V.Bundalo (1992) Low-temperature properties of thin films, Physica A, 184, 354-363.

[24] B.S.Tošić, V.D.Sajfert, D.Lj.Mirjanić, J.P.Šetrajčić (1992) Thermodynamical properties of ferroelectric films, J.Phys.Chem.Solids, 53, 1031-1039.

[25] S.Lazarev, D.Lj.Mirjanić, B.S.Tošić, J.P.Šetrajčić (1993) Microscopic approach to transport properties of crystals, Zbornik Matice srpske (pr.nauke), 85, 47-53.

[26] J.P.Šetrajčić M.Pantić (1994) Contribution to thermodynamic analysis of thin films, Phys.Lett.A, 192, 292-301.

[27] D.Lj.Mirjanić, J.P.Šetrajčić, M.Pantić, S.Lazarev (1994) Electron states in symmetrically deformed structures, Zbornik Matice srpske (pr.nauke), 85, 97106.

[28] B.S.Tošić, D.Lj.Mirjanić, J.P.Šetrajčić (1995) Spektri elementarnih pobuđenja u anizotropnoj film-strukturi - model superprovodnih keramika, Društvo fizičara Republike Srpske, Banja Luka. 
[29] J.P.Šetrajčić, M.Pantić, B.S.Tošić, D.Lj.Mirjanić (1995) Phonon states in broken-symmery thin films and some possible consequences on superconductivity, Bal.Phys.Lett., 2, 734-742.

[30] D.Lj.Mirjanić, S.M.Stojković, J.P.Šetrajčić, S.K.Jaćimovski (1995) Electron spectra in crystal films, IEEE: Proceedings 20th MIEL, 1, 177-179.

[31] J.P.Šetrajčić, S.M.Stojković,

S.Lazarev D.Lj.Mirjanić, M.Budinčević (1996) Green's functions method application on crystal structures with broken translational symmetry, Zbornik radova 10. PriM, p.73.

[32] J.P.Šetrajčić, D.Raković (1997) Fullerene C60 and Superconductivity - Fullerenes and Nanotubes Review, vol.1(4), IHIS Fullerenes Science \& Technology Center, Beograd.

[33] S.B.Lazarev, S.D.Markoski, D.Lj.Mirjanić, M.Pantić, J.P.Šetrajčić (1997) Spatial distribution of freecarriers in gaas films, IEEE: Proceedings 21st MIEL, 1, p.125.

[34] S.Lazarev, Ž.M.Škrbić, J.P.Šetrajčić, D.Lj.Mirjanić Lj.Ristovski (1997) Analysis of the localized excitations in polymer chain with impurities, J.Phys.Chem.Sol., 58, 793-804.

[35] J.P.Šetrajčić (1998) Superconductivity and fullerenes, Materials Science Forum, 282-283,71-83.

[36] J.P.Šetrajčić, S.M.Stojković, B.Abramović S.Lazarev (1998) Localized electron states in thin layered structures, Bal.Phys.Lett., 5, 414-425.

[37] S.Lazarev, D.Lj.Mirjanić, M.Pantić, B.S.Tošić, J.P.Šetrajčić (1999) Phonons in ultrathin layered structures, J.Phys.Chem.Sol., 60, 849-857.

[38] J.P.Šetrajčić, S.M.Stojković, S.B.Lazarev, I.D.Vragović, D.Lj.Mirjanić (1999) Dielectrical properties of thin molecular film-structures, SPIE-PL, Proc.5th International Conference on Dielectric and Related Phenomena (DRP), 37DP, p.162.

[39] S.M.Stojković, J.P.Šetrajčić, I.Junger, I.D.Vragović, S.B.Lazarev (2000) Electron spectra in simple superlattice, IEEE: Proceedings 22nd MIEL, 1, p.177.

[40] S.Lazarev, M.R.Pantić, S.M.Stojković, B.S.Tošić, J.P.Šetrajčić (2000) Thermodynamical properties of ultrathin layered structures, J.Phys.Chem.Sol., 61, 931-939.

[41] S.M.Stojković, J.P.Šetrajčić, I.D.Vragović (2000) Electron configuration of nanotubes, Materials Science Forum, 352, 129-137.

[42] [42] J.P.Šetrajčić (2001) Superprovodnost, Zmaj, Novi Sad.

[43] [43] S.M.Stojković, D.Lj.Mirjanić, J.P.Šetrajčić D.Šijačić, I.K.Junger (2001) Spectra and states of electrons in surface perturbed quantum wires, Surface Science, 477, 235-248.

[44] S.M.Stojković, B.S.Tošić, J.P.Šetrajčić, D.Popov (2002) Electrons in cylindrical quantum wires, IEEE: Proceedings 23rd MIEL, 1, p.389
[45] J.P.Šetrajčić, S.K.Jaćimovski, D.Raković, D.I.llić (2003) Phonon Spectra in Crystalline Nanostructures in Electrical and Computer Engineering Series: Advances in Simulation, Systems Theory and Systems Engineering, Eds. N.E.Mastorakis, V.V.Kluev and -D.Koruga, WSEAS Press, p.146.

[46] D.Popov, S.K.Jaćimovski, B.S.Tošić, J.P.Šetrajčić (2003) Kinetics of thin films mechanical oscillations, Physica A, 317, 129-137.

[47] J.P.Šetrajčić, S.M.Stojković, D.Lj.Mirjanić, S.M.Vučenović, D.Popov (2003) Influence of boundary conditions to the electron properties of thin films with two sublattices, Materials Science Forum ,413, 33-42.

[48] S.M.Vučenović, J.P.Šetrajčić, S.S.PelemiŠ, B.S.Tošić, D.Lj.Mirjanić (2004) Dielectric properties of molecular crystalline films, IEEE: Proceedings 24th MIEL, 1, p.279.

[49] S.K.Jaćimovski, J.P.Šetrajčić, B.S.Tošić, V.D.Sajfert (2004) Thermodynamics of mechanical oscillations in superlattices, Materials Science Forum, 453-454, 33-46.

[50] R.Kuzmanović, D.Lj.Mirjanić, B.Škundrić, M.Davidović, S.Sredić, J.P.Šetrajčić, S.M. Vučenović (2005) Teorijska i eksperimentalna istraživanja u nanomaterijalima, Zbornik radova ANURS, Banja Luka, p.233.

[51] B.S.Tošić, V.D.Sajfert, D.Popov, J.P.Šetrajčić, D.Ćirić (2005) Primena diferencionog računa u analizi nanostruktura, Vojvođanska akademija nauka i umetnosti, Novi Sad.

[52] V.D.Sajfert, J.P.Šetrajčić, S.K.Jaćimovski, B.S.Tošić (2005) Thermodynamic and kinetic properties of phonons in cylindrical quantum dots, Physica E, 353, 479-489.

[53] J.P.Šetrajčić, S.M.Vučenović, D.Lj.Mirjanić, V.D.Sajfert, S.K.Jaćimovski (2005) Exciton dispersion law and states of bimolecular thin films, Materials Science Forum, 494, 49-58.

[54] V.D.Sajfert, J.P.Šetrajčić, D.Popov, B.S.Tošić (2005) Difference equations in condensed matter physics and their applications to the exciton system in thin molecular film, Physica A, 353, 217-224.

[55] D.Backović, V.D.Sajfert, J.P.Šetrajčić, B.S.Tošić (2005) Magnetic nanorod in the transition temperature vicinity, J.Comput.Theor.Nanosci., 2(3), 448-455.

[56] W.T.S.Huck (Ed.) (2005) Nanoscale Assembly -Chemical techniques, Springer, New York.

[57] M.Adachi, D.J.Lockwood (Eds.) (2006) Selforganized nanoscale materials, Springer, New York.

[58] O.Manasreh (2005) Semiconductor heterojunctions and nanostructures, McGraw-Hill, New York.

[59] C.Delerue, M.Lannoo (2009) Nanostructures -theory and modelling, Springer, Berlin.

[60] H.E.Schaefer (2010) Nanoscience - The science of the small in physics, Engineering, Chemistry, Biology and Medicine, Springer, Berlin. 
[61] L.L.Chang, L.Esaki (1992) Semiconductor quantum heterostructures, Physics Today, 45(10), 36-43.

[62] M.C.Tringides, M.Jatochawski, E.Bauer (2007) Quantum size effects in metallic nanostructures, Physics Today, 60(4), 50-58.

[63] K.Wood, P.Hammond, D.Schmidt, S.Wrightman, B.Andaya (2008) Thin film delivers drugs, Biophotonics, Cambridge, Mass., (Feb.12, 2008); www.photonics.com.

[64] W.Frasch, D.Spetzler (2008) Tiny biosensor to detect DNA, Biophotonics, Tempe, Ariz. (March 26, 2008); www.photonics.com.

[65] M.G.Cottam, D.R.Tilley (1989) Introduction to surface and superlattice excitations, University Press, Cambridge.

[66] S.G.Davison, M.Steslicka (1996) Basic Theory of surface states, Oxford, Clarendon.

[67] M.Prutton- Surface Physics, Oxford Press, Clarendon (1984); Introduction to surface physics, Oxford Press, Clarendon (1995).

[68] D.L.Nika, N.D.Zincenco, A.A.Pokatilov (2009) Engineering of thermal fluxes in phonon mismatched heterostructures, J.Nanoelect.Optoelect., 4,180-195.

[69] V.M.Agranovich (1968) Theory of excitons, Nauka, Moskwa.

[70] V.M.Agranovich, V.L.Ginzburg (1979) Crystal optic with space dispersion and theory of excitons, Nauka, Moskwa.

[71] A.A.Maradudin (2007) Interaction of surface polaritons and plasmons with surface roughness, In: Surface polaritons, Eds.V.M.Agranovich, D.L.Mills, North-Holland, Amsterdam 1982. - pp.405-510; Light scattering and nanoscale surface roughness, Ed. A.A.Maradudin, In: Nanostructure science and technology, Ed. D.J.Lockwood, Springer, New York (2007).

[72] M.Combescot , W.Pogosov (2008) Microscopic derivation of frenkel excitons in second quantization, Phys.Rev. B, 77, 85-98.

[73] D.B.Balagurov, G.C.LaRocca, V.M.Agranovich (2003) Coherent-Potential-Approximation Study of Excitonic Absorption in Orientationally Disordered Molecular Aggregates, vol. 15, arXiv:condmat/0302312.

[74] J.P.Šetrajčić, V.M.Zorić, N.V.Delić, D.Lj.Mirjanić, S.K.Jaćimovski (2011) Phonon participation in thermodynamics and superconductive properties of thin ceramic films, Chapter 15, pp. 317-348, In „Thermodynamics”, Ed.M.Tadashi, ISBN: 978-953307-544-0, InTech, Vienna.

[75] V.D.Sajfert, Lj.D.Mašković, B.S.Tošić, J.P.Šetrajčić (2008) Linearization of single phonon hamiltonian and explanation the skin effect in cylindrical structures, J.Comput.Theor.Nanosci., 5(4), 587-590.

[76] I.D.Vragović, J.P.Šetrajčić, R.Scholz (2008) Quantum size effects in the optical properties of organic superlattices containing 3, 4, 9, 10 perylene tetracarboxylic dianhydride (PTCDA), Eur.Phys.J. B, $66,185-190$
[77] S.S.Pelemiš, J.P.Šetrajčić, B.Markoski, N.V.Delić S.M.Vučenović (2009) Selective absorption in two layered optic films, J.Comput.Theor.Nanosci., 6(7), 1474-1477.

[78] J.P.Šetrajčić, D.I.llić, B.Markoski, A.J.Šetrajčić S.M.Vučenović, D.Lj.Mirjani, B.Škipina, S.S.Pelemiš (2009) Adapting and application of the green's functions method onto research of the molecular ultrathin film optical properties, Physica Scripta T, $135,1-4$.

[79] S.K.Jaćimovski, B.S.Tošić, J.P.Šetrajčić, V.M.Zorić V.D.Sajfert, D.I.llić (2007)Thermodynamics of mechanical oscillations in crystalline superlattices Int.J.Mod.Phys. B, 21(6), 917-930.

[80] S.M.Vučenović, J.P.Šetrajčić, D.Lj.Mirjanić, B.Škipina (2007) Boundary influence on permittivity in molecular films, Acta Phys.Pol. A, 112, 963-968.

[81] V.D.Sajfert, Lj.D.Mašković, J.P.Šetrajčić, B.S.Tošić (2008) The stochastic approach in analysis the structures with vacancies and impurities, Int.J.Theor.Phys., 47, 1137-1146.

[82] B.Markoski, J.P.Šetrajčić, Lj.Džambas, D.Lj.Mirjanić, S.M.Vučenović (2009) Electron thermodynamics of nanofilm-structures, Mod.Phys.Lett. B, 23(2), 129135.

[83] J.P.Šetrajčić, D.Lj.Mirjanić, S.M.Vučenović, D.I.llić B.Markoski, S.K.Jaćimovski, V.D.Sajfert, V.M.Zorić (2009) Phonon contribution in thermodynamics of nano-crystalline films and wires, Acta Phys.Pol. A, $115,778-782$.

[84] N.V.Delić, B.S.Tošić, J.P.Šetrajčić, B.Markoski, S.S.Pelemiš, V.D.Sajfert, V.M.Zorić (2009) Photon's structure of motion, Acta Phys.Pol. A, 116(4), 471 475.

[85] S.S.Pelemiš, J.P.Šetrajčić, B.Markoski, N.V.Delić S.M.Vučenović, D.Lj.Mirjanić (2009) IR resonant absorption in molecular nanofilms, Acta Phys.Pol. A, 116(4), 579-584.

[86] S.M.Vučenović, J.P.Šetrajčić, B.Markoski, D.Lj.Mirjanić, S.S.Pelemiš, B.Škipina (2010) Changes in optical properties of molecular nanostructures, Acta Phys.Pol. A, 117, 764-767.

[87] S.K.Jaćimovski, B.S.Tošić, J.P.Šetrajčić, V.D.Sajfert (2010) Charge tunneling in doped quantum rod, Int.J.Mod.Phys.B, 24/27, 5345-5358.

[88] V.D.Sajfert, I.Vlajic-Naumovska, J.P.Šetrajčić M.Petrović, B.S.Tošić (2011) The stochastic approach to parallel spins analysis, J.Comput.Theor.Nanosci., 8(9), 1828-1830.

[89] V.D.Sajfert, S.K.Jaćimovski, J.P.Šetrajčić, Lj. Mašković, N.Bednar, N.Pop, B.S.Tošić (2011) Optical properties of nanostructures, J.Comput.Theor.Nanosci., 8(11), 2285-2290.

[90] B.Škipina, D.Lj.Mirjanić, S.M.Vučenović J.P.Šetrajčić, I.J.Šetrajčić, A.J.Šetrajčić-Tomić, S.S.Pelemiš, B.Markoski (2011) Selective IR absorption in molecular nanofilms, Optical Materials, 33, 1578-1584 
[91] B.Markoski, J.P.Šetrajčić, M.Petrevska, S.M. Vučenović (2012) Permittivity in perturbed molecular nanofilms, Int.J.Mod.Phys. B, 26(15), 123-138.

[92] J.P.Šetrajčić, B.Markoski, D.Rodić, S.S.Pelemiš, S.M. Vučenović, B.Škipina, D.Lj.Mirjanić (2013) Absorption features of symmetric molecular nanofilms,Nanoscience and Nanotechnology Letters, 5,1-5.

[93] S.M.Vučenović, B.Škipina, T.Grujić, J.P.Šetrajčić (2013) Refractive properties of molecular crystalline superlattices, J.Nonlinear Optic.Phys.Mater., 22(3), 1-9.

[94] J.P.Šetrajčić, S.Armaković, I.J.Šetrajčić, Lj.D. Džambas (2014) Surface localization of electrons in ultrathin crystalline structures, Mod.Phys.Lett. B, 28(4), 8-19.

[95] D.Rodić, B.Škipina, S.S.Pelemiš, S.K.Jaćimovski, J.P.Šetrajčić (2013) Selective ir absorption and refraction of symmetrical two-layered molecular nanofilms, Optica Applicata, 43(4), 643-649.
[96] B.Markoski, A.J.Šetrajčić-Tomić, D.Rodić, I.J. Šetrajčić, S.S.Pelemiš, J.P.Šetrajčić (2014) Some optical specificity of ultrathin crystalline films, Optik, $125,2830-2834$.

[97] S.K.Jaćimovki, J.P.Šetrajčić, M.S.Jaćimovski, V.V Stojanović (2014) Phonon contribution in thermodynamics and transport properties of ultrathin ceramic films, Acta Phys.Pol. A, 126/3, 811-819.

[98] J.P.Šetrajčić, S.K.Jaćimovski, V.D.Sajfert, I.J. Šetrajčić (2014) Specific quantum mechanical solution of difference equation of hyperbolic type, Commun.Nonlinear Sci.Numer.Simulat., 19(5), 1313-1328.

[99] I.J.Šetrajčić, D.Rodić, J.P.Šetrajčić (2015) Optical properties of layers of symmetric molecular nanofilms, Journal of Optics, 44/1, 1-6.

[100] J.P.Šetrajčić, S.K.Jaćimovski, V.D.Sajfert (2015) Phonon contribution to heat capacitance of nanolayered crystalline structures, Mod.Phys.Lett., B 29(4), 13-21.

\section{IZVOD}

\section{ISTRAŽIVANJE OSOBINA NANOSKOPSKIH STRUKTURA}

Cilj ovog rada je kreiranje modela ultratankih filmova, superrešetki, nanožica i kvantnih tačaka, $i$ istraživanje mikroskopskih i makroskopskih osobina ovih niskodimenzionih kristalnih sistema. Pokazano je da smanjenje dimenzije prostora $i$ granični uslovi imaju veliki uticaj na fizički relevantna svojstva u ovim kristalnim supstancijama. Rezonantna apsorpcija, različito ponašanje specifične toplote i kritične superprovodne temperature do $100^{\circ} \mathrm{C}$ su objašnjene.

Ključne reči: Elektroni, fononi, eksitoni, molekulske strukture, visoko-temperaturska superprovodnost, ultratanki filmovi, superrešetke, nano žice, kvantne tačke.

Pregledni rad

Rad primljen: 11.11.2015.

Rad prihvaćen: 31.12.2015.

Rad je dostupan na sajtu: www.idk.org.rs/casopis 